\title{
The Ornamental Fish Trade: An Introduction with Perspectives for Responsible Aquarium Fish Ownership ${ }^{1}$
}

\section{E. J. Livengood and F.A. Chapman² \\ Introduction}

Aquarium keeping is amongst the most popular of hobbies with millions of enthusiasts worldwide. Together all countries of the European Union are the largest market for ornamental fish; however, the United States (US) is the single largest importer of ornamental fish in the world (FAO 1996-2005; Chapman 2000). Although exact figures on the value and trade of the ornamental fish industry do not exist, the value of ornamental fish and invertebrates imported into different countries worldwide is approximately \$278 million US dollars (FAO 1996-2005). Pet industry surveys have estimated the aquarium industry worth over $\$ 1,000$ million USD (e.g., Cato and Brown 2003; AAPMA 2005).

Although most fish kept in aquariums are from freshwater, the acquisition of marine ornamental fish has greatly increased, popularized by children's movies starring charismatic colorful fishes and other creatures. Recent advances in fish husbandry and aquarium equipment technology have further facilitated the hobby.

There is a popular and rapidly expanding trend in the hobby to establish marine reef mini-ecosystems within the aquarium. Reef tanks are saltwater aquariums that house or center principally on invertebrates and minimize the number of fish. A typical reef tank makes use of live rock, both hard and soft corals, invertebrates such as crustaceans (e.g., crabs, hermit crabs, and shrimps), mollusks (e.g., snails, clams, and scallops), echinoderms (e.g., starfish, sand-dollars, and sea urchins), and of course, the endless variety of colorful fish. Consequently, the market value spent on many species of marine origin associated with the ornamental trade has greatly increased. For example, the retail value for a kilogram of coral reef fish destined for the aquarium trade may be worth $\$ 500$ to $\$ 1,800$ USD while a marine fish used for human consumption can be priced between $\$ 6$ and $\$ 16.50$ USD per kilogram (Cato and Brown 2003; Wabnitz et al. 2003).

\footnotetext{
1. This document is FA124, one of a series of the Department of Fisheries and Aquatic Sciences, Florida Cooperative Extension Service, Institute of Food and Agricultural Sciences, University of Florida.. First Published: May 2007. Please visit the EDIS Web site at http://edis.ifas.ufl.edu.

2. E. J. Livengood is a graduate student, School of Natural Resources and Environment; and F.A. Chapman is an Associate Professor, Department of Fisheries and Aquatic Sciences; Cooperative Extension Service, Institute of Food and Agricultural Sciences, University of Florida, Gainesville, FL 32611. All chemicals should be used in accordance with directions on the manufacturer's label. Use pesticides safely. Read and follow directions on the manufacturer's label. All chemicals should be used in accordance with directions on the manufacturer's label. The use of trade names in this publication is solely for the purpose of providing specific information. UF/IFAS does not guarantee or warranty the products named, and references to them in this publication does not signify our approval to the exclusion of other products of suitable composition. The use of trade names in this publication is solely for the purpose of providing specific information. UF/IFAS does not guarantee or warranty the products named, and references to them in this publication does not signify our approval to the exclusion of other products of suitable composition.
}

The Institute of Food and Agricultural Sciences (IFAS) is an Equal Opportunity Institution authorized to provide research, educational information and other services only to individuals and institutions that function with non-discrimination with respect to race, creed, color, religion, age, disability, sex, sexual orientation, marital status, national origin, political opinions or affiliations. U.S. Department of Agriculture, Cooperative Extension Service, University of Florida, IFAS, Florida A. \& M. University Cooperative Extension Program, and Boards of County Commissioners Cooperating. Millie Ferrer, Interim Dean 
Box 1. Industry definition of ornamental fish and live rock

Ornamental fish is often used as a generic term to describe aquatic animals kept in the aquarium hobby, including fishes, invertebrates such as corals, crustaceans (e.g., crabs, hermit crabs, shrimps), mollusks (e.g., snails, clams, scallops), and also live rock. Live rock is a general term for any type of rock encrusted with, and containing within its orifices, a wide variety of marine organisms including algae and colorful sessile invertebrates. Live rock serves as the principal biological and chemical filter in many marine-type tanks, and the encrusted organisms usually provide much of the background coloration in the tank.

The vast array of animal species that make up the generic 'ornamental aquarium fish trade' is staggering. Around 2,000 species and millions of specimens are traded annually in the ornamental fish trade (Table 1). The number of species is almost equally divided between freshwater and saltwater species. However, the greatest volume or number of individuals in the trade, some $90-96 \%$, are of freshwater origin and are produced in commercial aquaculture facilities (Chapman 1997; Cato and Brown 2003). important to remember that many species are also collected from the wild and are not in limitless supply.

To help promote resource sustainability, the potential aquarium owner should develop a basic understanding of the industry. Where did the species originate and were they wild-caught or farm-raised? Where did either practice occur, in what manner, and how were they handled during transport or before purchase? Local clubs, aquarium magazines, textbooks, Web sites in the Internet, and some specialized retailers can often answer many of these questions. A conscientious and well-informed consumer can greatly help protect wild species and safeguard the natural environment. Sustainability of a wild fisheries resource is critical to maintenance of a healthy industry.

\section{The collection and aquaculture of aquarium fish}

The vast majority of ornamental fishes in the aquarium trade is of freshwater origin and farm-raised. In the United States ornamental fishes are farmed principally in Florida. Other countries traditionally specializing in breeding and propagation of freshwater ornamental fishes are Thailand,

Table 1. Approximate number of fishes, corals, and other invertebrates in the ornamental (aquarium) trade. The majority of these species are collected from the wild. Only freshwater fish species are extensively farm-raised.

\begin{tabular}{|c|c|l|}
\hline Ornamental Species & Approximate Number of Species & \multicolumn{1}{|c|}{ Principal Geographic Regions } \\
\hline $\begin{array}{c}\text { Fresh-, Salt-, and Brackish- Water } \\
\text { Fishes }\end{array}$ & 1539 & $\begin{array}{l}\text { Southeast Asia, Americas, Africa, } \\
\text { Indonesia }\end{array}$ \\
\hline $\begin{array}{c}\text { Corals (hard and soft) } \\
\text { Invertebrates, other } \\
\text { (e.g., shrimps, crabs, snails, starfish) }\end{array}$ & 102 & $\begin{array}{l}\text { Indo-Pacific, Caribbean, the Red } \\
\text { Sea }\end{array}$ \\
\hline
\end{tabular}

Reference: various sources; principal, Cato, J.C., and C. L. Brown. 2003. Marine Ornamental Species: Collection, Culture, and Conservation.

An aquarium enthusiast can easily become overwhelmed by the endless variety of fish, invertebrates (including corals, anemones, mollusks), plants, and live rock available, and ultimately forget to consider their source and method of collection. Although many species in the hobby have been domesticated and are produced on farms, it is
Indonesia, Singapore, China (including Hong Kong), Malaysia, and Japan. More recently the culture of ornamental fish has shifted to regions near consumer centers. For example for the European market, many aquarium fish are now cultivated in countries such as the Czech Republic, Spain, Israel, Belgium, and Holland. Producing fish close to consumer centers is becoming more profitable because transport costs are greatly reduced. 
Facilities for the production of aquarium fish are often small compared to major food-fish production operations (Chapman 2000). Fishes are typically raised in small vats and outdoor-ponds, usually in conjunction with indoor facilities that house many small tanks and aquaria. There is a growing interest in the cultivation of ornamental fish in indoor facilities using water-recirculation systems. Cultivation practiced in indoor facilities takes advantage of current developments in husbandry methods and water filtration technologies. Farming ornamental fish in indoor facilities using water-recirculating systems can further minimize any potential impact to the environment by minimizing the escape of farmed fish and reducing water use. The small-scale nature of an ornamental fish farming system, both outdoors or indoors, minimizes any adverse impact to the environment, and seeks to optimize the use of land, labor, capital, and operational costs. hand nets, fish-holding buckets, and barrier nets serving to corral and fence the fish. Fishing occurs primarily from small boats anchored in shallow waters (less than ten meters, or about 30 feet) over coral reefs. Fish collected from the wild and destined for pet shops worldwide are typically collected in remote fishing sites. After collection, fish may spend from a few days to several weeks in fish camps before reaching importing and distribution warehouses worldwide. This time period is dependent on capture, storage, and transport logistics. In the fishing camps, the fish are typically separated by species, graded by size, and counted while awaiting a transport boat or local dealer. A local dealer using a transport boat, motorcycle, or just a bicycle may collect fish from various locations and maintain them in hauling boxes until they reach a secondary holding facility or storehouse. The fish are then mass consolidated, arriving from storehouses in different regions. In

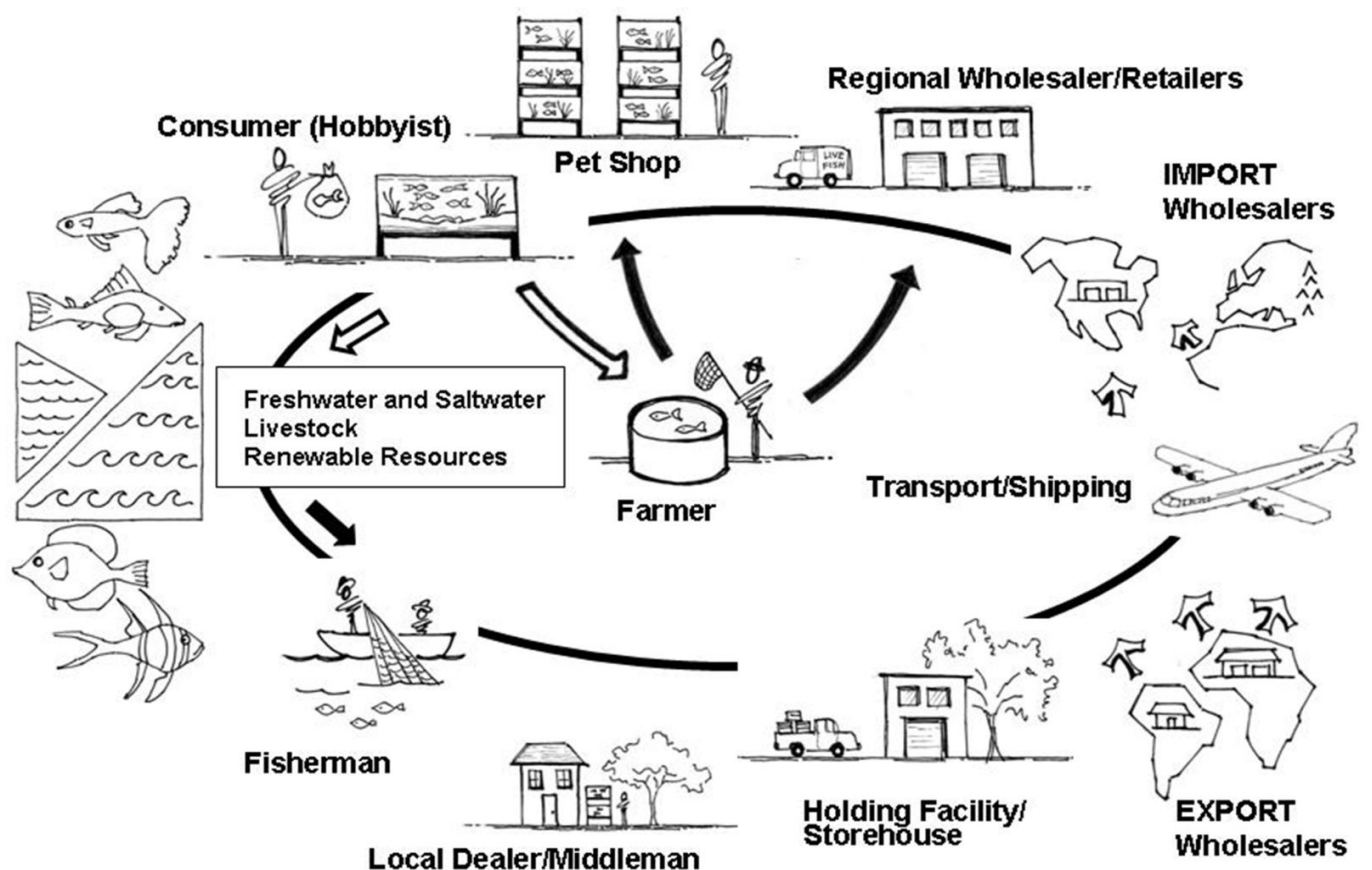

Figure 1. Schematic representation of typical distribution/trade process for livestock (e.g., fishes, corals, and other invertebrates) destined for ornamental aquarium use. The number of business intermediaries in the distribution chain depends primarily on the species (e.g., origin, abundance, popularity) and proximity to markets. The ornamental fish trade is driven primarily by consumer demand and environmental issues, hence the link from the consumer to the sustainable stocks or farmer. Credits: Frank A. Chapman

In the wild, most freshwater aquarium fish are caught primarily in rivers and streams using artisanal fishing methods consisting of small beach seines, dip nets, and a variety of small trap nets. In the collection of marine aquarium fish, diving gear (e.g., mask, snorkel and SCUBA) is commonly employed with local exporting warehouses, the fish are sorted again, placed in oxygenated bags, and air-shipped to major centers of distribution throughout the world (Figure $1)$. 
Countries that traditionally export wild-caught freshwater aquarium fish include Colombia, Peru, and Brazil in South America; Thailand and Indonesia in Southeast Asia; Congo, Nigeria, and Malawi in Africa. Singapore serves as the largest worldwide center and clearinghouse for the import, and export of both fresh and marine ornamental fish. Los Angeles, Miami, and Tampa are the major centers for the ornamental fish trade in the US. From these ports of entry, large importers, wholesalers, or trans-shippers may distribute fish to smaller franchises that sell to retailers that deal directly with home aquarists. In the exporting, importing, and larger warehouses, fishes are acclimated and water changes are provided for the shipping containers. To reduce transport costs, the trans-shipper primarily consolidates orders, receives, and redistributes the consignments generally without acclimatization of the fish. However, depending upon length of time between shipments and the number of fish sent to customers, some trans-shippers will also redistribute fish, re-oxygenate bags and do water changes for the transporting container.

Although some marine aquarium fish and invertebrates are aquacultured by the industry and hobbyists, most of the marine ornamentals:over 90\% are from wild-caught fisheries (Chapman 1997; Cato and Brown 2003) and generally command higher prices than freshwater fish (Chapman 1997; Cato and Brown 2003). The majority of the marine aquarium livestock originate from tropical oceans in the archipelagoes of Indonesia, the Philippines, Sri Lanka, the Maldives, and central Pacific Islands (e.g., Hawaii). Others are also imported from the Caribbean (e.g., Puerto Rico) and Red Sea regions.

\section{Important ecological considerations in the ornamental aquarium trade}

The purpose of managing a fishery is to maintain the resource so that it is renewable and therefore sustainable. Responsible aquaculture practices rely on sustainable production systems, to minimize impacts on the natural environment, and support resource conservation. In other words, the harvest of fish from the wild or their domestic culture, if performed with sound foundations in ecological and economic principles, can be sustainable and self-reliant commercial industries.
In traditional subsistence fisheries, fishermen use primitive and inefficient gear to capture most aquarium fish. However, supply of aquarium fish is not inexhaustible, and signs of over-fishing are becoming apparent in localized areas. With the high demand and pricing of many beautiful species, ornamental fish are being harvested at greater volumes and higher rates, threatening the viability or sustainability of the fishery (Chao et al. 2001; Gil and Martinez 2001; Vagelli and Erdmann 2002; Cato and Brown 2003; Lunn and Moreau 2004).

Unfortunately, in a few instances unscrupulous collection techniques have led to the demise of local fish populations. Alterations of natural riverine and marine habitats, caused by collection or other unrelated human activities, have also taken their toll. To facilitate the capture of aquarium fish in the wild, some collectors may use highly toxic substances such as sodium cyanide in marine environments, and rotenone in freshwater rivers and streams. The use of cyanide is not acceptable because it can have long-term deleterious health effects on the captured fish and the surrounding environment. Local populations of freshwater fish and their surrounding environment have also suffered from strip logging activities, oil drilling, and mining operations (e.g., increase in siltation and residues of toxic chemicals such as mercury for the extraction of alluvial gold). In South America, regional biologists indicate the indiscriminate use of herbicides and pesticides, to control the cultivation of plants used for manufacture of illicit drugs, percolate directly in the water stream deteriorating water quality and deleteriously affect the health of fish and invertebrate fauna.

The greatest losses of wild-caught aquarium fish may occur during the handling period between capture, local exporting/importing warehouses, and transportation docks. While in transit, fish may be subjected to physical injury, extreme changes in water quality conditions, water temperature fluctuations, and indiscriminate exposure to toxic chemicals used as prophylactic treatments for disease control. Also it has been determined that mortality of captured fish from the wild can be species dependant. For example, mortality has been estimated to be high (e.g., $80 \%$ ) in some marine tropical fish such as the Banggai cardinal fish to a low of $6 \%$ for some 
freshwater fish species such as the cardinal tetra (Chao et al. 2001; Gil and Martinez 2001; Vagelli and Erdmann 2002; Cato and Brown 2003; Lunn and Moreau 2004). To reduce injury and mortalities incurred in storage and post-shipment mortality, several of the larger importing wholesalers have established their own guidelines for fish collection, standardized handling procedures, and even assembled their own gathering stations or warehouses at major exporting centers worldwide. Local community-based organizations and international institutions have also been organized/formed to achieve market-driven product quality standards and sustainability in the marine aquarium industry. Post-shipment mortality (death-on-arrival) from exporter to importer has been greatly reduced to less than 5\% (Lim 2005).

Most of the 'live rock', corals, and invertebrates are also collected from the wild. The use of 'live rock' has increased drastically due to the rise in popularity of reef tanks. Collecting or mining of 'live rock' and many types of coral is conducted by snorkeling or wading, often using a hammer and chisel to remove pieces from the reef. Problems with wild-collection methods include generation of rubble and habitat damage. Fiji and Indonesia are currently the world's largest suppliers of 'live rock' and coral. The United States is the major importer of 'live rock' and corals (Cato and Brown 2003).

Culture of live rock and corals has increased with culture operations currently in the Indo-Pacific (Fiji, the Solomon Islands, Indonesia, and the Philippines) and the United States (Florida and Hawaii). Propagation of 'live rock' and many types of corals is conducted through a variety of methods. The most popular method utilizes pieces of limestone or other rock (or substrate), simply placed in selected areas on the sea floor, and allowed to be 'seeded' by a myriad of naturally occurring organisms, forming the 'live rock'. The 'live rock' can then be harvested after the organisms have achieved marketable size characteristics. More complex and labor intensive methods involve attaching coral fragments to selected pieces of rock, which are placed back into the wild or cultured in land-based operations. The clippings from the new growth are used in the reef tanks. The original parent stock may be left at sea to continue to grow and may also be used to seed previously damaged natural reefs.

High numbers of herbivorous animals, such as hermit crabs, snails, and shrimps, are harvested annually for the aquarium trade. Observations and management of a mini-reef tank in our laboratory highlights the essential role of these invertebrates in minimizing growth of algae and other organisms. Without grazers, algae may quickly dominate a reef. Since animals occupying different trophic levels have valuable roles in the wild, overfishing of key species may have important ecological consequences. Fortunately, there is an increased interest and technology emerging to culture these valuable and highly sought invertebrates.

\section{Being an educated consumer}

Being an aquarist and fish hobbyist is enjoyable, relaxing, and an educational and rewarding experience. Like owners of other traditional pets (such as dogs, cats, and birds), aquarists maintain livestock that require a strong commitment and responsibility for the welfare of the animals. Daily and weekly requirements must be met.

- Responsible aquarists must recognize they are working with live animals that have been either farm-raised or wild-caught, the final destination being a home or public aquarium. Part of the responsibility of the aquarium hobbyist is to know the origin of the aquarium fish and the practices used for their collection. Unlike traditional pets, most marine fish, shrimps, corals, and other marine animals kept in aquaria are wildlife and undomesticated. Although many of the commonly sold freshwater species are aquacultured, many others are still wild caught. Although the supply of aquarium fish from the wild is renewable, many of the species are limited to a particular geographic region and have specialized life-history strategies that may limit their abundance. The ornamental fish trade follows regular economic demands and it is important to ensure that a continuous supply for this hobby is maintained. Inexpensive fish are usually abundant whereas rare fish can be more expensive. 
- Potential aquarists should obtain reliable information on the source and biology of the livestock, knowledge of their husbandry, and keeping methods. Correct information is often not offered to the consumer, so it is important to acquire some basic knowledge of the trade and fish husbandry before a hobbyist begins their tank. Although information will vary by pet store, the important thing is to ask questions. Acquiring the information about your species and their potential to interact with other species, their true origin, and their physiological requirements are the first step to optimizing welfare of your fish as well as gaining useful knowledge of the trade.

- Preparing the aquarium to receive and support plant and animal life are prerequisites for a successful aquarium. Part of this preparation includes understanding the importance of water quality management. (See Web links listed under "Cited Literature and Additional Resources"). Before animals are introduced, the aquaria must have a natural or artificial form of water filtration to remove toxic substances, especially ammonia, released by most aquatic animals as a natural by-product of protein metabolism. If using a biological filter, it should be allowed to fully develop the beneficial bacteria to carry out the nitrogen cycle, required to remove the ammonia. Animals in the aquarium must also have a supply of nutritious foods. The feed must be supplied judiciously to prevent obesity and to avoid water quality deterioration by promoting excess ammonia and concentration of other nutrients.

- All animal and plant life should be quarantined before introduction into an established aquarium system to prevent the introduction of disease. In addition to maintenance of good water quality, proper sanitation and proper nutrition are essential practices for disease prevention.

- Aquariums should be covered to prevent fish from jumping out. Proper lighting is essential for the health of all animals, plant life, and also for aesthetic reasons - to best display the wide variety of colors exhibited by the many life forms in the aquarium.
- Most people choose fish, corals, and other invertebrates from tropical warm waters because they tend to be more colorful. However, because these animals cannot regulate their body temperature, the water in the aquarium must be maintained at the animals optimal range. Hobbyists that maintain organisms from temperate or coldwater regions must chill the water if ambient conditions are too warm. Because of potential temperature differences in holding and receiving waters, the animals and plants should be acclimated to holding water before being released into the aquarium.

- A responsible aquarist must have a plan for proper care or disposal of fish and other livestock that they can no longer keep, or that have become ill or died. Do not release live exotic fish into the wild or dispose by flushing them down the toilet. Such actions can be detrimental to the environment and the animal. Attempt to return or exchange the unwanted animal at the pet shop, trade with another responsible aquarist or contact someone from your local aquarium society for help. A local school or animal care center may serve as repository for the care of such unwanted animals. For sick animals or for assistance with euthanasia, consult with a veterinarian or fish health specialist. As a last resort, animals can also be killed by placing them in ice-water. The reduced water temperature places the fish into topor or dormancy before death. This method of using ice has not been approved and is under current investigation.

- Most importantly, the consumer should not think of fish as a disposable item, especially with those rare and difficult to obtain species. Realization that many fish, corals, and other invertebrates are, in fact, wildlife will help with understanding the environmental implications of the aquarium trade. Since many of the aquarium inhabitants are collected directly from the wild, the sustainability of a wild fisheries resource is critical to a healthy industry. Learning about the species chosen by asking the retailer questions and becoming an educated consumer is the key to becoming a responsible aquarium fish owner. 


\section{Cited literature and additional resources}

Information is readily available through local aquarium clubs, in books, aquarium magazines, the Internet and other similar sources. For a collection of information on topics relevant to ornamental fish care, health management, and this industry, the University of Florida IFAS EDIS Web site (http://edis.ifas.ufl.edu) and Tropical Aquaculture Laboratory (http://tal.ifas.ufl.edu) homepages are good starting points.

\section{Web links}

Aquatic Nuisance Species Task Force Partnership, representing the Pet Industry Joint Advisory Council, US Fish and Wildlife and NOAA National Sea Grant College Program, to prevent non-native species introductions. http://www.habitattitude.net

Industry driven marketing campaign to educate consumers in aquarium keeping.

http://www.diveintofish.com

IATA Live animal regulations (LAR). http://www.iata.org/ps/publications/9105.htm

FishBase: a global information system on fishes "with all you ever wanted to know about fishes," including common and scientific names; topics related to ecology and life history. http://www.fishbase.org

\section{University of Florida Cooperative Extension Service EDIS publications on ornamental aquaculture, fish health management, and welfare}

- Freshwater Ornamental Fish Commonly Cultured in Florida: http://edis.ifas.ufl.edu/FA054

- Aquarium Set-Up and Maintenance: http://edis.ifas.ufl.edu/VM107

- Ammonia: http://edis.ifas.ufl.edu/FA031

- Fish Nutrition: http://edis.ifas.ufl.edu/FA096

- Introduction to Fish Health Management: http://edis.ifas.ufl.edu/FA004
- Stress-Its Role in Fish Disease:

http://edis.ifas.ufl.edu/FA005

- Fish Health Management in Recirculating Aquaculture Systems:

- Part 1-Introduction and General Principles: http://edis.ifas.ufl.edu/FA099

- Part 2-Pathogens: http://edis.ifas.ufl.edu/FA100

- Part 3-General Recommendations and Problem-Solving Approaches: http://edis.ifas.ufl.edu/FA101

- Regulations Pertaining to Non-Native Fish in Florida Aquaculture: http://edis.ifas.ufl.edu/FA121

\section{Other informative sites sponsored by industry}

Pet Industry Joint Advisory Council (PIJAC). Complete pet information source including fishes. http://www.peteducation.com

Marine Aquarium Council.

http://www.aquariumcouncil.org

Aquariums, fish and aquatic information. http://www.wetwebmedia.com

APPMA. 2005. National Pet Owners Survey. American Pet Products Manufactures Association. http://www.appma.org

\section{Journal articles and books}

Adey, W. H. and K. Loveland. 1998. Dynamic Aquaria. San Diego, CA: Academic Press.

Axelrod, H.R., G.S. Axelrod, W.E. Burgess, B.M. Scott, N. Pronek, and J.G. Walls. 2004. Atlas of Freshwater Aquarium Fishes. Neptune City, NJ: T.F.H. Publications, Inc.

Brunner, B. 2003. The Ocean at Home: An Illustrated History of the Aquarium. New York, NY: Princeton Architectural Press.

Burgess, W.E., H.R. Axelrod, and R. Hunziker. 1991. Atlas of Marine Aquarium Fishes. Neptune City, NJ: 
T.F.H. Publications, Inc.

Cato, J.C. and C.L. Brown. 2003. Marine Ornamental Species: Collection, Culture, and Conservation.

Ames, IA: Iowa State Press.

Chao, N.L., P. Petry, G. Prang, L. Sonneschien, and M. Tlusty. 2001. Conservation and Management of Ornamental Fish Resources of the Rio Negro Basin, Amazonia, Brazil-Project Piaba. Manaus, BR: Editora da Universidade do Amazonas (EDUA).

Chapman, F.A. 2000. Ornamental fish culture, freshwater. In: R.R. Stickney (ed), Encyclopedia of Aquaculture, pp. 602-610. New York, NY: John Wiley \& Sons, Inc.

Chapman, F.A., S.A. Fitz-Coy, E.M. Thunberg, and C.M. Adams. 1997. United States of America trade in ornamental fish. Journal of the World Aquaculture Society 28:1-10.

Gil, H.R. and R.E.A. Martinez. 2001. La Pesca En La Baja Orinoquia Colombiana: una vision integral. Instituto Nacional de Pesca y Acuicultura (INPA).

FAO, Food and Agriculture Organization of the United Nations. 1996-2005. The numbers represent the average unit value of imports for 1994-2003. FAO Yearbooks 1996 to 2005, Fishery Statistics, Commodities Volumes 83-97. FAO:Rome, Italy.

Fernando, A.A., and V.P.E. Phang. 1994. Freshwater Ornamental Fish Aquaculture in Singapore.

Singapore, SG: Singapore Polytechnic.

Gratzek, J.B. 1994. Aquariology: The Science of Fish Health Management. Morris Plains, NJ: Tetra Press.

Kasselmann, C. 2002. Aquarium Plants. Malabar, FL: Krieger Publishing Company.

Lim, L.C. 2005. Ornamental fish packing system for air transport: reduction of post-shipment mortality through quality enhancement. OFI Journal 48:94-100.

Lunn, K.e. and M.A. Moreau. 2004. Unmonitored trade in marine ornamental fishes: the case of Indonesia's Banggai cardinalfish (Pterapogon kauderni). Coral Reefs 23:344-351.
Socolof, R.B. 1996. Confessions of a Tropical Fish Addict: A History of the Tropical Fish Industry in Florida. Bradenton, FL: Socolof Industries.

Sprung, J. 2001. Invertebrates: A Quick Reference Guide. Miami, FL: Ricordea Publishing.

Vagelli, A.A. and M.V. Erdmann. 2002. First comprehensive ecological survey of the Banggai cardinalfish, Pterapogon kauderni. Environmental Biology of Fishes 63:1-8.

Wabnitz, C., M. Taylor, E. Green, T. Razak. 2003. From Ocean to Aquarium. Cambridge, UK:

UNEP-WCMC 